\title{
Assessment of the Profitability and Viability of Catfish Marketing in Onitsha North and South Local Government area of Anambra State Nigeria
}

\author{
Samuel O. Igwe ${ }^{1 *}$, Terhemba E. Chancha ${ }^{2}$, Blessing G. Umbugadu ${ }^{2}$ and Beatrice G. Dauda ${ }^{1}$ \\ ${ }^{1}$ Department of Agricultural Economics and Extension, Federal University Wukari \\ Taraba State, Nigeria
}

${ }^{2}$ Department of Agricultural Economics, College of Agricultural Economics and Extension Management Technology, Federal University of Agriculture Makurdi, Benue State, Nigeria

${ }^{*}$ Corresponding author's email: sammyigwe [AT] gmail.com

\begin{abstract}
The study was carried out in Onitsha north and Onitsha south local government area of Anambra State Nigeria. The main objective of the study was to assess the profitability and viability of catfish marketing. Data were collected with structured questionnaires administered to 65 randomly selected catfish marketers. Mean, frequency, percentages, gross margin, Net profit, Gross margin ratio, Operating ratio and Return on investment were all employed to analyze the objectives. The result revealed that transportation cost is the most militating factor against catfish marketing in Onitsha north and Onitsha south local government area of Anambra State Nigeria. The study also revealed that, catfish marketing in the study area was profitable and viable with return on Investment (ROI) of $22.17 \%$ and a Gross Margin ratio of $18.14 \%$. The study therefore, recommends that government should provide storage facility and rehabilitate our roads to reduce the cost of transportation in marketing.
\end{abstract}

Keywords---- profitability, viability, catfish, marketing, gross margin

\section{INTRODUCTION}

Catfish are highly diverse Ostariophysan fishes with a probable ancestral benthic habit and are commonly found in fresh water on all continents except Antarctica.

In Nigeria, the contribution of the fisheries sub-sector to agriculture GDP was estimated to be $4.0 \%$ in the year 2007, out of the total estimate of $40 \%$ being contributed by agriculture to the GDP (FDF, 2008). The Food and Agricultural Organization of the United Nations (FAO, 2006), stated that Nigeria is a protein-deficient country. Protein deficiency in diet can be primarily remedied through the consumption of either protein-rich plants or animals; which catfish is one of the sources.

Catfish is the major fish cultured in Nigeria because it is found all over the Country, eaten by most tribes, resistant to harsh environmental conditions, commands good price, tasty and can be kept alive for days during marketing. Estimates put the current production output of Clarias gariepinus in the Country at over 253,898 metric tonnes per year (FDF, 2013).

Currently, about $90 \%$ of fish farm in Nigeria is catfish; during the last four years, almost all hatchery infrastructure and table fishes production systems have exclusively targeted toward catfish production due to its unquantifiable benefit to human existence in terms of dietary composition in all meals (FDF, 2005). As a result of this, according to FAO (2006a), fish supply in Nigeria amounts to 400,000 tons of supply in comparism to the 800,000 tons of demand. This makes Nigeria one of the largest importers of fish in the developing world, importing above 600,000 metric tons annually (Moehl, 2003). According to Olasunkanmi, (2012) Increasing demand for fish products has resulted in the growth of fish farms to meet a substantial part of the world's food requirement.

\section{STATEMENT OF THE PROBLEM}

Nigeria is one of the less developed countries of the world with average protein intake below the estimated minimum standard per individual (Olayide, 1976). Globally, fish provides about 3.0 billion people with almost 20 percent of their intake of animal protein, and 4.3 billion people with about 15 percent of such protein (FAO, 2012). Catfish is one of the good sources of animal protein that would help to improve this trend. Despite the overwhelming importance of catfish as a source of protein globally, low availability, low level of profit margin, low protein intake and other related constraints have remained a huge challenge even when the production of catfish seems to be on the increase. 
It is in view of these amongst other issues that this study seeks to assess the profitability and viability of catfish marketing in Onitsha north and south LGA of Anambra state Nigeria.

The study therefore is set out with the following specific objectives to;

i. delineate the socioeconomic of catfish marketers in Onitsha north and Onitsha south local government area of Anambra state Nigeria

ii. determine factors militating against catfish marketing in Onitsha north and Onitsha south local government area of Anambra state Nigeria

iii. assess the profitability and viability of catfish marketing in Onitsha north and Onitsha south local government area of Anambra state Nigeria

\section{Study Area}

\section{METHODOLOGY}

The study was carried out in Onitsha north and Onitsha south local government area of Anambra state Nigeria. The state is bordered by Enugu state, Imo state, Delta state, and Abia state. The state has a total population of 4,182,032 of which 2,174,641 are males while 2,007,391 are females (NPC, 2006). The local government areas are found within the rainforest belt or zones. Their major occupation is trading and commerce, fishing activities and transportation.

\section{Population of the Study}

The population for the study was 650 registered catfish sellers in the study area.

\section{Sampling Techniques}

The study employed multistage sampling technique in selecting sample size of catfish sellers in Anambra state. First stage was purposive selection of two local government areas in Anambra state namely; Onitsha south and Onitsha north local government area. In the second stage was random selection of four (4) catfish markets in the two local government area of Anambra state in stage one above. The third stage was random selection of 20 catfish sellers at Ose markets, 15 catfish sellers from Ochanja market, Bridge head market and Onitsha main market respectively to arrive at a sample size of 65 catfish sellers. However, the reason for the selection of 20 catfish sellers in Ose market was as a result of high dominance of catfish marketers.

\section{Methods of Data Collection}

The method of data collection for the study was through primary and secondary sources. Primary sources of data collection were through structured questionnaire and in-depth interview. While, secondary source of data collection was done through reviews of relevant journals.

\section{Methods of Data Analysis}

The data collected for the study were analyzed using descriptive and inferential statistics. Descriptive statistics such as, mean, table, percentages and frequency were all employed for data analysis while gross margin, Net profit, Gross margin ratio, Operating ratio and Return on investment were all employed to assess the profitability and viability of catfish marketing in Onitsha south and Onitsha north local government area of Anambra states, Nigeria.

Pseudo Profit function:

Profit $(\pi)=$ Total Revenue - Total Cost.

Gross margin $(\mathrm{GM})=$ Total Revenue $(\mathrm{TR})-$ Total variable cost $(\mathrm{TVC})$

Net Profit $(\mathrm{NP})=\mathrm{GM}-\mathrm{TFC}($ depreciated value $)$

GMR $=\frac{\text { GM }}{\mathrm{TR}} \times 100$

Operating Ratio $(\mathrm{OR})=\underline{\mathrm{TVC}} \times 100$

$\mathrm{ROI}=\frac{\mathrm{GM}}{\mathrm{TVC}} 100$

TVC

Where $; \mathrm{TR}=$ Total Revenue,$\quad \mathrm{TVC}=$ total variable cost, $\mathrm{TFC}=$ total fix cost $\mathrm{GM}=$ Gross Margin, GMR = Gross Margin Ratio, $\mathrm{OR}=$ Operating Ratio ROI $=$ Return on Investment, NP $=$ Net Profit . 


\section{RESULT AND DISCUSSION}

\section{Demographic Characteristics of the Respondents}

\section{Sex distribution}

Table 1 shows the distribution of sex of the respondents. The results revealed that, 58(89\%) of catfish marketers in the study area were female while, $7(11 \%)$. The results showed that catfish marketing is mostly engage by the female than their male counterpart.

Table 1 showing distribution of sex of respondents

\begin{tabular}{lll}
\hline Sex & Frequency & Percentage $(\%)$ \\
\hline Male & 7 & 11 \\
Female & 58 & 89 \\
Total & 65 & 100 \\
\hline
\end{tabular}

\section{Age distribution of the respondents}

Table 2 below shows the age distribution of respondents. The result revealed that, majority age of catfish marketers were $21-30(24.6 \%), 31-40(23.1 \%), 41-50(18.5 \%), 51-60(16.9 \%)$. This indicates that, between 21-60 lies the active age of catfish marketers.

Table 2 showing distribution of age of the respondents

\begin{tabular}{lll}
\hline Age & Frequency & Percentage $(\%)$ \\
\hline$<20$ & 8 & 12 \\
$21-30$ & 16 & 25 \\
$31-40$ & 15 & 23 \\
$41-50$ & 12 & 19 \\
$51-60$ & 11 & 16 \\
$>60$ & 3 & 5 \\
Total & 65 & 100 \\
\hline
\end{tabular}

\section{Distribution of marital status of the respondents}

Table 3 below shows the distribution of marital status of the respondents for the study. The results indicate that, $46(71 \%)$ catfish sellers were married while $19(29 \%)$ were single. This implies that catfish marketing is mostly practice by married persons as it contributes to their household income.

Table 3 showing distribution of marital status of respondent

\begin{tabular}{lll}
\hline Marital status & Frequency & Percentages (\%) \\
\hline Married & 46 & 71 \\
Single & 19 & 29 \\
Total & 65 & 100 \\
\hline
\end{tabular}

\section{Distribution of the number of years spent in school of the respondent}

Table 4 below shows the distribution of educational status of the respondents. The findings from the study revealed that, $19 \%$ had formal education, $46 \%$ had primary education, and 35\% had secondary education while none had tertiary education. The result implies that at least most of the catfish sellers had elementary education that makes them understand the basic business mathematics.

Table 4 showing the distribution of number of years spent in school by the respondents

\begin{tabular}{lll}
\hline No. of years spent in school & Frequency & Percentage (\%) \\
\hline No education & 12 & 19 \\
Primary & 30 & 46 \\
Secondary & 23 & 35 \\
Tertiary & 0 & 0 \\
Total & 65 & 100 \\
\hline
\end{tabular}

\section{Distribution of number of years in catfish marketing}

Table 5 below shows distribution of numbers of years spent in catfish marketing by the respondents. The result revealed that, majority $22(34 \%)$ had spent above 10years in catfish marketing, 20(31\%) spent 1-5years in catfish marketing, 
$15(23 \%)$ spent 6-10years in the marketing of catfish in Onitsha north and Onitsha south local government area of Anambra state Nigeria. it means that a majority number of the respondents are experienced and have been into catfish business over the years.

Table 5 Showing distribution of number of years in catfish marketing

\begin{tabular}{lll}
\hline Years spent in catfish marketing & Frequency & Percentages $(\%)$ \\
\hline$<1$ & 8 & 12 \\
$1-5$ & 20 & 31 \\
$6-10$ & 15 & 23 \\
$>10$ & 22 & 34 \\
Total & 65 & 100 \\
\hline
\end{tabular}

\section{Factors Militating against Catfish Marketing in Anambra state}

Table 6 below identified the factors militating against catfish marketing in Onitsha south and Onitsha north local government area in Anambra state as opined by respondents as; Lack of finance, Lack of credit facilities, inconducive environment, High cost of transportation, In adequate storage, Seasonality. Above all the factors highlighted, the study revealed that transportation cost is the most affected factor militating against catfish marketing.

Table 6: Showing the distribution of the Factor militating against catfish marketing

\begin{tabular}{lll}
\hline Factors & Frequencies $(\mathrm{F})$ & Percentages $(\%)$ \\
\hline Lack of finance & 13 & 21.7 \\
Lack of credit facilities & 8 & 13.3 \\
In conducive environment & 12 & 20 \\
High cost of transportation & 20 & 30 \\
In adequate storage & 9 & 15 \\
Seasonality & 3 & 5 \\
Total & 65 & 100 \\
\hline
\end{tabular}

Profitability and viability analysis of catfish marketing in Onitsha north and south LGA of Anambra state:

Table 7 below shows the result of the profitability and viability of catfish marketing in Onitsha north and south LGA's of Anambra using; gross margin, net income, gross ratio, return on investment and operating ratio. The results revealed that catfish marketing is a profitable and viable with average total revenue of $25,641.63 / 50 \mathrm{~kg}$; Gross margin of $\$ 4,652.47 / 50 \mathrm{~kg}$; and return on investment of $22.17 \%$. This means that catfish marketing is a profitable and viable in the study area. 
Table 7: Showing Profitability and viability analysis of catfish marketing in Onitsha north and south LGA of Anambra state:

\begin{tabular}{|c|c|c|c|c|c|}
\hline Markets & $\begin{array}{l}\text { Main } \\
\text { market }\end{array}$ & $\begin{array}{l}\text { Amount in } \\
\text { A } / 50 \mathrm{~kg} \\
\text { Ose } \\
\text { markets }\end{array}$ & $\begin{array}{l}\text { Ochanja } \\
\text { markets }\end{array}$ & Bridge $\mathrm{H}$ & Ave \\
\hline Total Revenue (TR) & 25,850 & 26,000 & $24,191.50$ & 26,525 & $25,641.63$ \\
\hline \multicolumn{6}{|l|}{ Variable/operating cost } \\
\hline i. $\quad$ Cost Price & 19,775 & 19,900 & 19,608 & $20,108.50$ & $19,847.88$ \\
\hline Packaging cost & 180 & 150.6 & 100 & 120 & 137.65 \\
\hline Disposable Apron & 200 & 180.8 & 150 & 180 & 177.88 \\
\hline Transportation & 585 & 721 & 367 & 512 & 546.25 \\
\hline Storage charges & 358 & 282 & 243 & 235 & 279.50 \\
\hline Total Variable Cost (TVC) & 21,098 & $21,234.40$ & 20,468 & $21,155.50$ & $20,989.16$ \\
\hline \multicolumn{6}{|l|}{ Fixed cost (depreciated cost) } \\
\hline i. $\quad$ Table & 28.8 & 35.3 & 25.6 & 30.0 & 29.93 \\
\hline Pan/basin & 35.0 & - & 35.8 & - & 35.4 \\
\hline Cutting board & 10.0 & 12.0 & 10 & 8.0 & 10.0 \\
\hline Axe & 20.0 & 25.0 & - & - & 35.4 \\
\hline Shop rentage & 32.5 & 25.0 & 15.0 & - & 24.17 \\
\hline Market charges & - & - & 20.0 & 24.0 & 22.0 \\
\hline Scale & 65.8 & 50.0 & - & 45.8 & 53.87 \\
\hline Total Fixed Cost (TFC) & 192.1 & 147.3 & 106.4 & 107.8 & 197.86 \\
\hline $\operatorname{Gross} \operatorname{Margin}(\mathrm{GM})=(\mathrm{TR}-\mathrm{TVC})$ & 4,752 & $4,765.60$ & $3,722.50$ & $5,369.50$ & $4,652.47$ \\
\hline \multicolumn{6}{|l|}{ Net Income $(\mathrm{NI})=(\mathrm{GM}-\mathrm{TFC})$} \\
\hline \multicolumn{6}{|l|}{ GM Ratio $=(\mathrm{GM} / \mathrm{TR}) \%$} \\
\hline $\begin{array}{l}\text { Operating } \\
\text { Ratio }(\mathrm{OR})=(\mathrm{TVC} / \mathrm{TR}) \%\end{array}$ & 18.38 & 18.33 & 15.39 & 20.24 & 18.14 \\
\hline \multirow[t]{2}{*}{$\mathrm{ROI}=(\mathrm{GM} / \mathrm{TVC}) \%$} & 81.61 & 81.67 & 84.61 & 79.76 & 81.85 \\
\hline & 22.52 & 22.44 & 18.19 & 25.38 & 22.17 \\
\hline
\end{tabular}

\section{CONCLUSION AND RECOMMENDATIONS}

The study revealed that catfish marketers in the study area are dominated by experienced middle aged married women with basic education. It was also revealed that lack of finance, inconducive environment, high transportation cost and lack of storage facility were the major factors militating against catfish marketing in the study area. It also showed that catfish marketing is profitable and viable.

Therefore, it is recommended that the government should provide financial support, good environment, storage facility and good transportation network for the marketers who make their livelihood from the business and also contributes to food security.

\section{REFERENCES}

- Food and Agricultural Organisation(FAO). Fisheries development in Nigeria; the current challenges. Paper presented by the honorable of state for agriculture to the fisheries society of Nigeria (FISON) Lagos state. pp.23, 2007 
- $\quad$ Food and Agricultural Organisation. The state of world fisheries and aquaculture, Rome. pp. 209. 2012

- Food and Agricultural Organisation(FAO). Nigerias fisheries profile. www.fao.org/fi/fcp/en/NGA, 2006a

- Food and Agricultural Organisation(FAO). Year book of Fishery Statistics Summary Table. www.fao.org/fi/statist.asp , 2006.

- $\quad$ Federal Department of Fisheries (FDF). Federal Department of Fisheries. Press Report of the Federal Ministry of Agriculture and Water Resources Abuja. Delivered by the Director of Fisheries at NiconNoga Hilton Hotel on 24th December, 2013.

- Federal Department of Fisheries (FDF). Report of Presidential Committee on Fisheries and Aquaculture Development: Consolidated Report. Vol. 1. Pp,3 71, 2005.

- Moehl, J. Gender and aquaculture development in Africa FAO Aquaculture news Letter, July, No 29 Rome, 2003.

- National Population Commission (NPC). National Population Census 2006 Provisional Results, Abuja, Nigeria. pp. 21, 2006.

- Okpeke, M.Y. and Akarue, B.O.. Analysis of the profitability of fish farming in Warri South Local Government area of Delta state, Nigeria. Journal of Agriculture and Veterinary Sciences 8(12): pp.45-51, 2015

- Olasunkanmi, J.B. Economic Analysis of Fish Farming in Osun State, South - Western Nigeria: Proceedings of The International Institute of Fisheries Economics and Trade, Tanzania. Pp.1 - 10, 2012

- Olayide, S.O., Ogunfowora, O., and Essay, S.M. Element of Rural Economics, University Press, Ibadan. pp. 35,1976 